\title{
ORIGINALISM OFF THE GROUND: A RESPONSE TO PROFESSORS BAUDE AND SACHS
}

\author{
Eric J. Segall*
}

Professors Will Baude and Stephen Sachs are a legal realist's worst nightmare. In their Northwestern Law Review essay "Grounding Originalism," they continue their Arthurian quest to convince the legal world that originalism has been and currently is our law. They denote this effort a "positivist" account of our legal practices and claim theirs is a more accurate description of constitutional law than competing theories such as common law constitutionalism and pluralistic decision-making. Although they discuss H.L.A. Hart and contemporary philosophers, they concede that "the more enduring dispute between us and many of our critics is far more banal: it's a simple empirical disagreement. Maybe our beliefs seem odd . . . because other readers don't see how our existing legal practice grounds a form of originalism."

As one of their critics, ${ }^{3}$ our disagreements, far from being "banal," implicate fundamental principles of constitutional interpretation and judicial transparency. To legal realists, and most political scientists who study the Supreme Court, originalism is just one of many methods of constitutional discourse, and only a slight one. Far from being our law, originalism is used by judges mainly as a rhetorical device to justify decisions reached on other grounds. ${ }^{4}$ There is substantial data, as well as detailed descriptive accounts by experts, that strongly suggest that where judges have

* Kathy \& Lawrence Ashe Professor of Law, Georgia State University College of Law. Thanks to Richard Primus and Heidi Kitrosser for helpful comments on an earlier draft.

1. William Baude \& Stephen E. Sachs, Grounding Originalism, 113 Nw. U. L. REV 1455 (2019) [hereinafter Grounding Originalism].

2. Id. at 1477 . (2016).

3. See Richard A. Posner \& Eric J. Segall, Faux Originalism, 20 GREEn BAG 2d 109

4. See ERIC J. SEgall, ORIGINALISM AS FAITH 156-57 (2018) [hereinafter FAITH]. 
legal discretion, their values, experiences, and politics determine the sum and substance of our law. ${ }^{5}$ Those values, experiences, and politics, as this essay will show, do not reflect the values of people living in 1787 or 1868 , or the law of that time, but our judges' values today. The weakest aspect of Baude and Sachs' recent essay, and their other detailed and complicated efforts to portray originalism, not just as part of our law, but as our law, is their failure to wrestle directly with legal realist and political science critiques of judicial decision-making.

In Grounding Originalism, Baude and Sachs describe constitutionalism at such a high level of abstraction that they fail to see how non-originalist values drive the substance of our actual law. They also concede that "originalism can be a correct descriptive account of our legal system, even if few people would currently describe our system that way." That claim does not sound in legal positivism, which presumably requires an account of how people actually think about, describe, and then act towards our real legal practices on the ground.

This essay starts by summarizing Baude and Sachs' arguments. Then it shows that their account, ironically given their self-professed positivism, fails to wrestle with court decisions on the ground. They try to make up for that failure by claiming judicial decisions aren't law, and by categorizing obviously nonoriginalist opinions as originalist, but they are mistaken in both views at least to the extent they purport to care about how constitutional law operates as opposed to philosophic and linguistic academic debates far removed from legal practice. This essay concludes that if Baude and Sachs are going to continue their zeal to claim originalism is our law, they inevitably must directly address the legal realist account of judicial decisionmaking and show why it is inaccurate.

\section{THE CORE CLAIMS}

In Grounding Originalism, Baude and Sachs distill their prior work into three "core claims." First, "[t]heories of legal interpretation ought to give more emphasis to questions of law. Whatever a theory's conceptual elegance or normative attractions, it also matters whether that theory already reflects our

5. See id.; infra Part 3.

6. Grounding Originalism, supra note 1, at 1465. 
law, or is instead a call for law reform." Second, "the particular rules of our legal system happen to endorse a form of originalism. Our law today incorporates our original law by reference." 8 Third, " $[t]$ he binding force of our original law has important consequences for the present day. .. . The original-law approach may be capacious in theory, but it's exacting in application."

These three "core claims" can be summarized as follows: A theory of legal interpretation must reflect our actual practices, not recommendations for changing those practices. Our legal system as it has existed and currently exists is one of originalism, meaning our law is the founders' law until it is lawfully changed according to well-accepted principles approved by the founders. This claim does not mean that legal outcomes never change but rather they must change in accordance with the founders' rules for how legal change can occur. Baude and Sachs also argue that this descriptive account can be accurate even in the face of a strong pattern of non-originalist judicial outcomes. ${ }^{10}$

Despite non-originalist decisions, they argue, we measure and discuss constitutional law cases in the context of originalist arguments and evidence. Moreover, they claim that "[o]riginal meaning sometimes explicitly prevails over policy arguments in constitutional adjudication, but the reverse doesn't seem to be true," and "there are no clear repudiations of originalism as our law in the current canon of Supreme Court cases, even in situations where the Justices must have been sorely tempted." 11

In sum, our law is the original law, as changed according to the original rules for change, and the important participants in our legal and political systems act as if both accounts are true.

\section{THE ORIGINAL LAW ISN'T OUR LAW}

Baude and Sachs' description of originalism's place in our current law does not reflect how the American people, nonjudicial governmental actors, and judges participate in our legal and political systems. I have argued, as have others, that the Court's constitutional law jurisprudence is far removed from our

\footnotetext{
7. Id. at 1457 .

8. Id. (footnote omitted).

9. Id. at 1458 (quotation omitted).

10. See id. at 1476-77.

11. Id. at $1477-78$.
} 
original Constitution, as amended, and the day-to-day operations of our law are not the "founder's' law."12 The examples of country-changing non-originalist Supreme Court decisions fill casebooks, treatises, and law review articles. For example, University of Richmond Law Professor Jud Campbell recently and persuasively argued that the Court's complicated and comprehensive common law free speech doctrines have not been justified (and probably could not be justified) by the First Amendment's original meaning. ${ }^{13}$

Although there have been a few valiant efforts to the contrary, the dominant academic view is that Brown v. Board of Education is also inconsistent with an originalist method of constitutional interpretation, ${ }^{14}$ as are the recent same-sex marriage cases. ${ }^{15}$ Baude and Sachs themselves have previously listed a bevy of important cases they think might be inconsistent with the Constitution's original meaning, including Reynolds $v$. Sims' blockbuster one-person, one-vote holding, the Court's standing doctrine as articulated in Lujan v. Defenders of Wildlife, and many of the Court's important commerce clause cases giving Congress almost unlimited power to regulate local economic activities.${ }^{16}$ I could, and I'm guessing they could, go on and on, and then on some more.

If this much of constitutional law is non-originalist, how can originalism possibly be our law? Baude and Sachs make two specific responses and one general one. Their first rebuttal, fleshed out in greater detail in other works, is that some decisions that most scholars label non-originalist actually derive from originalist criteria and reasoning (even if they are right about this, which they are not, as noted above they too have pointed to a

12. See FAITH, supra note 4, at 172-73; Richard Primus, Is Theocracy Our Politics?, 116 COLUM. L. REV. SiDEBAR 44, 51 (2016).

13. See Jud Campbell, Natural Rights and the First Amendment, 127 YALE L.J. 246 (2017); see also Heidi Kitrosser, Interpretive Modesty, 104 GEO. L.J. 459, 491 (2016) (“[I]t is far from clear that 'the right to criticize

Government' is the original meaning of the First Amendment.").

14. See Ronald Turner, The Problematics of the Brown-Is-Originalist Project, 23 J.L. \& POL'Y 591 (2015).

15. See Orin Kerr, Is There an Originalist Case for a Right to Same-Sex Marriage?, WASH. POST (Jan. 28, 2015), https://www.washingtonpost.com/news/volokhconspiracy/wp/2015/01/28/is-there-an-originalist-case-for-a-right-to-same-sexmarriage/?utm_term $=.4812$ faa6c10f.

16. See William Baude \& Stephen E. Sachs, Originalism's Bite, 20 GreEn BAG 2d 103, 108 (2016). 
hefty chunk of non-originalist decisions). Thus, in a prior work, Baude argued that Obergefell $v$. Hodges,${ }^{17}$ despite language which many interpret as rejecting originalism, actually embraces originalism. Here is the language in question:

$[T]$ he generations that wrote and ratified the Bill of Rights and the Fourteenth Amendment did not presume to know the extent of freedom in all of its dimensions, and so they entrusted to future generations a charter protecting the right of all persons to enjoy liberty as we learn its meaning. When new insight reveals discord between the Constitution's central protections and a received legal stricture, a claim to liberty must be addressed. ${ }^{18}$

It is difficult to imagine a stronger rejection of originalism than this passage. Nevertheless, in his essay "Is Originalism Our Law," Baude argued that "this sort of living originalism" amounts to the Court asking the right questions and doing "what an inclusive originalist would do." 19 Thus, "even in one of its most potentially anti-originalist moments, the Court ultimately claimed fidelity to the Amendment's original authors." 20

Baude made similar arguments about non-originalist passages in Brown v. Board of Education and other cases by essentially saying that these cases asked the right question: what did the Fourteenth Amendment originally require judges to do? And if the answer is to allow evolutionary decision-making by judges based on changed facts and values, then those decisions are part of the originalist canon. ${ }^{21}$ In "Grounding Originalism," Baude and Sachs restate this idea as "the Founder's' law allowed for various kinds of changes," including a form of living constitutionalism where judges may find that "[a] given rule of law may be a function of what the custom is today, because that's what the Founder's' law prescribed back then, which is what our law tells us to care about today." 22

As I've argued elsewhere, both on my own, and with retired Judge Richard Posner, ${ }^{23}$ if Baude and Sachs are correct that

17. 135 S. Ct. 2584 (2015).

18. Id. at 2598 (emphasis added).

19. William Baude, Is Originalism Our Law?, 115 COLUM. L. REV. 2349, 2382-83 (2015).

20. Id. at 2383 .

21. See Grounding Originalism, supra note 1, at 1491.

22. Id.

23. Posner \& Segall, supra note 3. 
sometimes, maybe even much of the time, the founders' instruction to judges was to take into account contemporary values and judgments, then originalism and non-originalism merge, and we could just as easily say living constitutionalism and pluralistic methods of constitutional interpretation are "our law." Many if not most non-originalist constitutional law professors and judges also claim that their respective methods are grounded in fidelity to constitutional practice, history, and meaning. They argue that the application of vague constitutional text to new circumstances requires the selection of judicial value choices because hard cases have always required judges to make such choices, as the founders expected by using such imprecise language. ${ }^{24}$ This argument sounds similar to the observations made by Baude and Sachs quoted above. For the constitutional provisions that most often lead to litigation (we don't need theories of interpretation for precise text such as the President has to be 35), originalism and non-originalism require the same evolutionary analysis, and there is little at stake between adopting one label or the other.

Baude and Sachs also argue in "Grounding Originalism" that lawyers, judges, writers of amicus briefs, and virtually everyone else involved in trying to flesh out constitutional meaning employ originalist arguments to support their own views and criticize their opponents' arguments. ${ }^{25}$ They are correct that advocates and judges employ historical arguments where they can, but Baude and Sachs ignore the reality that constitutional players also use policy and value judgments to criticize Court decisions. The Justices' abortion decisions were wrong because the fetus is a human being, ${ }^{26}$ same-sex marriage dooms traditional marriage, ${ }^{27}$

24. See Erwin Chemerinsky, The Jurisprudence of Justice Scalia, 22 U. HAW. L. REV. 385,494 (2000).

25. See Grounding Originalism, supra note 1, at 1484-85.

26. See Brief for Wisconsin et al. as Amici Curiae Supporting Petitioners, Box v. Planned Parenthood of Ind. \& Ky., Inc., No. 18-483 (U.S. Nov. 15, 2018), https://www.supremecourt.gov/DocketPDF/18/18-483/72184/20181115122354603_18483\%20Brief\%20of\%20States \%20of\%20Wisconsin \%20et\%20al\%20Supporting \% 20 Petitioners.pdf.

27. See Brief for 100 Scholars of Marriage as Amici Curiae Supporting Respondents, Obergefell v. Hodges, 135 S. Ct. 2584 (2015) (Nos. 14-556, 14-562, 14-571 \& 14-574), https://www.scribd.com/document/261172376/100-Scholars-of-Marriage-Amicus-Brief. 
Citizens United increases the role of money in politics, ${ }^{28}$ affirmative action programs lead to stigma and backlash, ${ }^{29}$ and so on. Constitutional law comes with a heavy mix of legal and policy content, and Baude and Sachs have not tried to make an empirical showing that one transcends the other. We could say "policy arguments are our law."

Additionally, to say that scholars, lawyers, and judges regularly employ originalist arguments means very little given that there are as many different versions of originalism as there are competing theories of constitutional interpretation. As Professors Peter Smith and Tom Colby have repeatedly shown, originalism is "not a single, coherent, unified theory of constitutional interpretation, but rather a smorgasbord of distinct constitutional theories that share little in common except a misleading reliance on a single label." ${ }^{30}$ Some originalists think that strong judicial deference is an essential part of originalism, others think judges have a duty of clarity which is not quite as deferential, while most so-called New Originalists, and even some traditional ones, think judges should aggressively review state and federal laws. ${ }^{31}$

There are originalists who believe in the interpretationconstruction distinction suggesting a difference between the semantic, non-legal meaning of constitutional text and the application of that text to hard cases, while other originalists think that it is "Orwellian to describe [a theory that leaves room for construction] as 'originalist' in any meaningful sense of that term." 32 Given the wide latitude originalists have to make their arguments while retaining the label "originalist," virtually any legal theory today can be comfortably placed inside that rubric (Baude and Sach's' views that Obergefell might be so classified is

28. See Michael Beckel \& Jared Bennett, 12 Ways "Citizens United" Has Changed Politics, CTR. FOR PUB. INTEGRITY (Jan. 21, 2015), https://publicintegrity.org/federalpolitics/12-ways-citizens-united-has-changed-politics/.

29. See Brief of Richard Sander \& Stuart Taylor, Jr. as Amici Curiae Supporting Petitioner, Fisher v. Univ. of Tex. at Austin, 570 U.S. 297 (2013) (No. 11-345), http://sblog.s3.amazonaws.com/wp-content/uploads/2011/11/Sander-Taylor-brief.pdf. (2009)

30. Thomas B. Colby \& Peter J. Smith, Living Originalism, 59 DUKE L.J. 239, 244

31. See FAITH, supra note 4, at 82-121 (discussing the many different flavors of originalism).

32. Martin H. Redish \& Matthew B. Arnould, Judicial Review, Constitutional Interpretation, and the Democratic Dilemma: Proposing a "Controlled Activism" Alternative, 64 FLA. L. REV. 1485, 1509 (2012). 
a classic example). If that is what Baude and Sachs mean by originalism is our law, that observation is basically a truism with little relevance to cases on the ground or the arguments that lawyers make and judges adopt or reject.

The strong claim by Baude and Sachs that "[o]riginal meaning sometimes explicitly prevails over policy arguments in constitutional adjudication, but the reverse doesn't seem to be true, ${ }^{33}$ is just not accurate. They don't provide evidence in their article supporting this claim, but an entire era of Warren Court constitutional law was based mostly on justice and fairness while often ignoring or minimizing text and history. ${ }^{34}$ The landmark decision in Griswold v. Connecticut ${ }^{35}$ finding a right to privacy to use contraception, which was later used in Roe v. Wade, is four pages long without any historical analysis. The supremely important decision in Reynolds v. Sims,${ }^{36}$ laying down the oneperson, one-vote rule, has no originalist content while the dissent relied on the long judicial history and tradition allowing states to choose their own redistricting methods. ${ }^{37}$

As noted earlier, Sims is on Baude and Sachs' list of potentially non-originalist cases, a fair observation, but the case does show that overt policy concerns can trump originalist sources even in the most important cases. The list of such examples is long and includes the Court's libel and slander jurisprudence, gay rights cases, affirmative action decisions striking down state and federal racial preferences without a word about the original meaning of the Fifth and Fourteenth Amendments, and many others. Contrary to Baude and Sachs' account, when it comes to Supreme Court decisions, in the words of Richard Primus, "[i]t is what the Court has been doing that is our law, and a big part of what the Court has been doing is deciding cases ... in ways that are not consistent with original meanings." 38

The last move made by Baude and Sachs to support their claim that originalism is our law (despite the enormous evidence to the contrary) is to suggest that court decisions aren't law at all

33. See Grounding Originalism, supra note 1, at 1477.

34. See FAITH, supra note 4, at 52-55 (describing important non-originalist Warren Court decisions).

35. 381 U.S. 479 (1965).

36. 377 U.S. $533(1964)$

37. See id. at 589 (Harlan, J., dissenting).

38. Primus, supra note 12, at 51-52 (cited in Grounding Originalism, supra note 1, at 1464). 
(even though they may be binding) and therefore even when those decisions are wrong on an originalist basis, all that means is that the Court didn't follow the rules correctly, not that originalism isn't the rule (or our law). They argue the following:

[U]nder our system's rules of precedent, legal actors are sometimes commanded to follow a Supreme Court decision "as if" it were the law-even as the underlying legal materials, which command ultimate authority, prescribe a different result. ... [L]ower courts can be bound to an erroneous Supreme Court decision by principles of stare decisis, requiring them to treat the decision "as if" it properly stated the law. This "as if" law can be binding on particular actors without thereby becoming the law-much the way a runner can be called "out" by an umpire and treated as if he were "out" for the remainder of the game, though in truth he actually touched the plate first and was safe. ${ }^{39}$

Elsewhere, Sachs has argued that legal opinions can be a "source of law," and can be res judicata or the law of the case, but "each does so by treating the judicial decision as if it were law, and not by substituting that decision for the underlying legal standards on which it's based." 40 For example, he argues, the Fourth Circuit's decisions are binding in Maryland but not Delaware, "even though the same Fourth Amendment applies in each state." Moreover,

[t]he same theory can be applied to courts of last resort. . . . [T]here's no reason why the holdings of a court like the Supreme Court of the United States must necessarily be taken to represent 'the law,' as opposed to 'the law of the Supreme Court,' binding on other courts within the reach of its appellate jurisdiction. ${ }^{41}$

Arguing that judicial decisions are not law is a key move for Baude and Sachs. They are trying to bridge the gap from their concession that much of our judge-made law isn't originalist to their conclusion that our actual law is still originalist because judicial decisions aren't law like the Constitution (and statutes) are law. When umpires make mistakes, the rules of baseball don't change, and when judges make mistakes, the rules of

\footnotetext{
39. Grounding Originalism, supra note 1, at 1472 (footnotes omitted).

40. Stephen E. Sachs, Finding Law, 107 CALIF. L. REV. 527, 561 (2019).

41. Id. 562-63.
} 
constitutional law (originalist methods) don't change, or so they argue.

The problem with this theory is that, for all practical purposes, Supreme Court decisions are the supreme law of the land until such decisions are reversed either by courts or constitutional amendment. It does not matter what academics or philosophers say about whether these decisions are "law" any more that it matters whether an umpire's call was right or wrong once the game is over and the outcome determined. Critics labeling a legal decision incorrect because it is inconsistent with our founder's' original law does not deprive that decision of its status as binding law to the people of the United States, local and state governments, Congress, and the President. As I've argued elsewhere:

[F]or all practical purposes, the Constitution means what the Supreme Court says it means, which is why Georgia can't yet prohibit all abortions, Montana can't regulate corporate political speech the way it wants to, and Alabama must recognize same-sex marriages. Philosophers can debate whether court decisions are "law," in a technical sense ... and we can all debate whether or not originalism is our law as a theoretical manner. But two things are true: 1) constitutional law evolves and changes every term even though the text remains exactly the same, and 2) non-judicial political actors and the American people treat court decisions as law from traffic courts all the way up to the Supreme Court. That being the case, it is more than perplexing . . . that legal positivists would argue that court-made law isn't real law. ${ }^{42}$

In Planned Parenthood v. Casey, ${ }^{43}$ Justices Souter, O'Connor and Kennedy announced that our "Constitution is a covenant running from the first generation of Americans to us and then to future generations. It is a coherent succession. Each generation must learn anew that the Constitution's written terms embody ideas and aspirations that must survive more ages than one." 44 Whether or not these words have the status of law, they describe a system of law that is decidedly non-originalist, which brings us back to the most important argument Baude and Sachs make

42. Eric Segall, Are Court Decisions Law, and Why that Matters to Whether Originalism Is Our Law, DORF ON LAW (Feb. 11, 2019), http://www.dorfonlaw.org/2019/02/are-court-decisions-law-and-why-that.html.

43. 505 U.S. 833 (1992).

44. Id. at 901 . 
about why originalism is our law. They claim that "[a] given rule of law may be a function of whatever the custom is today, because that's what the Founders' law prescribed back then, which is what our law tells us to care about today." 45 If each generation of judges can redefine what the vague text of the Constitution means to them, today, because that is what the founders' wanted them to do back then, then it doesn't matter whether legal opinions are law or just binding pieces of paper because the founders' law allows judges to reject the values, principles, and judgments of the relevant ratification eras in today's legal cases. If that makes originalism our law, the theory applies equally to most forms of living constitutionalism.

\section{REALIST AND POLITICAL SCIENCE CRITIQUES}

The even deeper flaw in the picture Baude and Sachs paint of our system of constitutional law and constitutional judging has to do with how judges decide constitutional cases. As I argued in my recent book "Originalism as Faith," and as legal realists and most political scientists have long believed, "legal sources such as text, history, precedent, and prior positive law play less of a role in the justices' decision making than their political and personal values." 46 There is a vast academic literature supporting these arguments. ${ }^{47}$ As Dean Chemerinsky famously said, "[c]onstitutional law is now, will be, and always has been, largely a product of the views [and values] of the Justices." 48 Less theoretically, Senator Sheldon Whitehouse recently claimed that from 2006-2018, in cases raising direct political stakes the GOP cared about regarding elections, voting, campaign finance reform, and related issues, the GOP-controlled Supreme Court voted in 73 out of 73 cases in ways that supported the Republican Party. ${ }^{49}$ Even if that number were 63 out of 73 , the point would remain

45. Grounding Originalism, supra note 1, at 1491 (emphasis added).

46. FAITH, supra note 4, at 156.

47. See Jeffrey A. Segal \& Harold J. Spaeth, The Supreme Court and the AtTitudinAl MODEL REVISITED (2002). (1989).

48. Erwin Chemerinsky, The Vanishing Constitution, 103 HARV. L. REV. 43, 100

49. See Sheldon Whitehouse, There's a 'Crisis of Credibility' at the U.S. Supreme Court, NAT'L L.J. (Feb. 15, 2019), https://www.law.com/nationallawjournal/ 2019/02/15/sen-whitehouse-theres-a-crisis-of-credibility-at-the-u-s-supreme-court/ ?slreturn $=20190121083108$. 
that the best descriptor of those cases would not be "originalist" but rather a combination of GOP values and politics.

In "Grounding Originalism," Baude and Sachs offer two brief, almost perfunctory responses to the idea that the Court is a "super legislature" where text and history play second fiddle to values and politics. First, they argue the following:

[B]ut if the Supreme Court really is a super-legislature, its members have some odd preferences regarding their policy agenda. . . . [I]nstead of acting like normal legislators and addressing salient topics like tax rates or gas prices, the Justices instead possess an extensive desire to meddle around in federal sentencing, an outsized and politically unpredictable interest in the details of criminal procedure, and an abiding fascination with Internet pornography. ${ }^{50}$

This argument, that the Court has an "odd policy agenda," is beside the point. The Court, of course, chooses its own agenda, and there is little or no discussion anywhere in the literature regarding whether the Justices use originalist criteria when doing so. More importantly, the Court doesn't decide to hear seventyfive front-page, hot-button cases a year because if they did, the Justices' political value judgments would be clear to everyone. If most of the Court's cases dealt with abortion, affirmative action, gun reform, and the like, the "law gig" would be up. But nothing in Baude' and Sachs' article wrestles with the reality that conservative Justices usually vote for conservative results while liberal Justices reliably vote for liberal results, regardless of what text and history show. The fact that the Court often hears disputes that don't raise political stakes tells us little about the role originalism plays in the most important cases. Currently, "our law" of abortion, affirmative action, campaign finance reform, separation of powers, gay rights, the commerce clause, and numerous other hugely important topics simply has very little to do with the original meaning of the Constitution, and a lot to do with the political values of Justices Sandra Day O'Connor and Anthony Kennedy, one of whose votes was needed in virtually every divided constitutional law decision from 1988-2018. Neither Justice can be fairly characterized as an originalist.

The second argument made in Grounding Originalism that is relevant to the realist critique is that the authors suggest that the

50. Grounding Originalism, supra note 1, at 1490 (footnotes omitted). 
reasons and arguments litigators use to advance their client's' cases, and the reasons the Justices use to explain their decisions, often sound in originalism even if the results are inconsistent with our founders' law. They point to the recent Emoluments litigation and the avalanche of scholarly originalist arguments on all sides, and conclude the following:

[C]lients spend good money hiring lawyers to dig up originalist evidence - the stronger the evidence, the better-which is then treated as meaningful even by those who rarely describe themselves as originalists. This suggests that originalism isn't merely something at which to genuflect before moving on to the real grounds of decision, for then the quality of originalist argument wouldn't matter so much. If originalism is a ritual, it's a ritual that obeys the full form of legal argument. If originalism is a pretense, the pretense runs deep. ${ }^{51}$

There are serious omissions in these arguments. First, as noted earlier, there are generations of important Supreme Court cases that don't spend any time on originalist arguments. Baude and Sachs respond that "citation practices don't tell us all (or even most) of what we want to know about the deep structure of law." 52 Maybe not, but the "deep structure of the law" doesn't resolve cases, judges do. The history of the Supreme Court, according to legal realists and the vast majority of political scientists, is mostly the history of politics and values, not text and history, and the evidence is in the cases themselves. Baude and Sachs are making an empirical point when they claim that the deep structure of our law is originalist, but they have so far failed to make any showing through detailed case analysis that they are right. Conversely, legal realists and political scientists have devoted enormous time and effort to parsing actual language and results of Supreme Court cases and comparing those to the Justices' well-known political views to support the realist case that values not law determine constitutional outcomes. ${ }^{53}$ It takes data to beat data,

51. Id. at 1485-86 (footnote omitted).

52. Id. at 1481 .

53. See Chemerinsky, supra note 48; Richard Primus, Limits of Interpretivism,' 32 HARV. J.L. \& PUB. POL'Y 159, 171 (2009) (“[I]n a great many cases, judges seem to conclude that the relevant original meanings support the same results that we suspect they would reach if they had not consulted original meanings. To whatever extent that suspicion is justified, original meanings are not functioning as constraining rules."); Jacobus tenBroek, Use by the United States Supreme Court of Extrinsic Aids in Constitutional Construction, 27 CALIF. L. REV. 399 (1939). 
case law to beat case law, and Baude and Sachs have not attempted such an analysis.

Finally, almost the entire point of legal realism is that legal doctrine generally, including originalism, is a "pretense that runs deep." Judges aren't historians, but they know how to put together favorable arguments and discredit unfavorable ones to support their value judgments. Even in those few cases that contain substantial historical content, such as District of Columbia v. Heller ${ }^{54}$ and U.S. Term Limits, Inc. v. Thornton, ${ }^{55}$ involving issues of first impression and therefore the examination of first principles, the Justices' uses of history are both amateurish and inevitably circle back to their political priors, not a sincere effort to understand the founders' law. ${ }^{56}$

Given the strong correlation between the Justices' values and their votes over more than 150 years of constitutional decisionmaking, the burden of showing that non-values-based, originalist reasons best describe our law falls squarely on Baude and Sachs, and so far they have not illustrated their abstract arguments with detailed discussions of constitutional law doctrine. Until they do so, originalism might be our law in some academic, theoretical sense, but on the ground, where we look to the Supreme Court for binding rules relating to abortion, affirmative action, federalism, separation of powers, and other hugely important questions, our rules reflect the Justices' values, not the values of people who lived long ago.

\section{CONCLUSION}

In one of the most influential Supreme Court separation of powers cases in our history, Youngstown Steel and Tube Co. v. Sawyer ${ }^{57}$ Justice Robert H. Jackson said the following:

[J] ust what our forefathers did envision, or would have envisioned had they foreseen modern conditions, must be

54. 554 U.S. 570 (2008) (invalidating D.C. law banning handguns).

55. 514 U.S. 779 (1995) (invalidating Arkansas term limits on members of Congress).

56. See FAITH, supra note 4, at 141-47 (arguing virtually no historians agree with either the majority or dissent in Heller); Eric Segall, Justice Kennedy's Constitution and Why We Need It Now More Than Ever, DORF ON LAW (June 5, 2017), http://www.dorfonlaw.org/2017/06/justice-kennedys-constitution-and-why.html

(observing that the key vote in Thornton was Justice Kennedy's, who eschewed history for values).

57. 343 U.S. 579 (1952). 
divined from materials almost as enigmatic as the dreams Joseph was called upon to interpret for Pharaoh. A century and a half of partisan debate and scholarly speculation yields no net result but only supplies more or less apt quotations from respected sources on each side of any question. They largely cancel each other. ${ }^{58}$

This famous statement applies equally to virtually every litigated area of constitutional law. ${ }^{59}$ In the most important civil rights case the Court ever decided,${ }^{60}$ the Court said the following:

[I]n approaching this problem, we cannot turn the clock back to 1868 when the Amendment was adopted, or even to 1896 when Plessy v. Ferguson was written. We must consider public education in the light of its full development and its present place in American life throughout the Nation. Only in this way can it be determined if segregation in public schools deprives these plaintiffs of the equal protection of the laws. ${ }^{61}$

The most important swing Justice of our (and probably any) generation had this to say about originalism:

$[\mathrm{H}]$ ad those who drew and ratified the Due Process Clauses of the Fifth Amendment or the Fourteenth Amendment known the components of liberty in its manifold possibilities, they might have been more specific. They did not presume to have this insight. They knew times can blind us to certain truths and later generations can see that laws once thought necessary and proper in fact serve only to oppress. As the Constitution endures, persons in every generation can invoke its principles in their own search for greater freedom. ${ }^{62}$

If originalism is our law, the Supreme Court is doing a great job hiding that fact from the American people. More accurately, originalism is a cover for personal values, or less pejoratively, a matter of faith for the American people, legal scholars, and judges to pretend the Court cares about text and history when deciding cases when what the Justices really privilege are their own prior decisions, values, and politics. The history of constitutional law jurisprudence is not fidelity to the founders' views but judges applying their own values to vague principles in the context of new

\footnotetext{
58. Id. at 634-35 (Jackson, J., concurring).

59. See FAITH, supra note 4 , at $156-70$.

60. Brown v. Bd. of Educ., 347 U.S. 483 (1954).

61. Id. at 492-93.

62. Lawrence v. Texas, 539 U.S. 558, 578-79 (2003).
} 
problems. Originalism may or may not be a valid aspiration, but it is not our law in any way that matters, down here on the ground. 